\title{
TFAP2A Gene
}

National Cancer Institute

\section{Source}

National Cancer Institute. TFAP2A Gene. NCI Thesaurus. Code C18559.

This gene is involved in transcriptional activation of genes which are required for development of ectodermal tissues. It also plays a role in the negative regulation of chondrocyte differentiation. 